\title{
PERSEBARAN INDUSTRI BATIK DI BANDUNG, CIREBON, DAN TASIKMALAYA 1967-1998
}

\author{
THE PRESENCE OF THE BATIK INDUSTRIES \\ IN BANDUNG, CIREBON, AND TASIKMALAYA DURING 1967-1998
}

\author{
Aziz Ali Haerulloh ${ }^{1}$, Etty Saringendyanti ${ }^{2}$, Ayu Septiani ${ }^{3}$ \\ ${ }^{1,2,3}$ Departemen Sejarah dan Filologi \\ Fakultas Ilmu Budaya Universitas Padjadjaran \\ Jl. Raya Bandung-Sumedang KM 21, Hegarmanah, Kec. Jatinangor, Kab. Sumedang. \\ e-mail: aziz.alihaerulloh30@gmail.com, ettypuar@gmail.com, ayu.septiani@unpad.ac.id
}

DOI: 10.30959/patanjala.v13i1.662

\begin{abstract}
Abstrak
Penelitian ini menggunakan metode sejarah yang terdiri dari tahapan heuristik, kritik, interpretasi, dan historiografi, serta menggunakan pendekatan sosial ekonomi untuk menjelaskan secara kronologis pengaruh adanya persebaran industri batik terhadap kesejahteraan masyarakat Bandung, Cirebon, dan Tasikmalaya. Penelitian ini menggunakan sampel dalam mencari dan mengumpulkan data. Berdasarkan hasil penelitian studi pustaka, studi lapangan, observasi, dan wawancara, menunjukkan bahwa penyebaran budaya membatik berpengaruh terhadap munculnya industri batik yang berada di Bandung, Cirebon, dan Tasikmalaya. Ketiga daerah tersebut memiliki peran dalam menciptakan lapangan pekerjaan bagi masyarakat sekitar yang memiiki keahlian dalam membatik, baik tulis maupun cap. Selain itu, industri batik di tiga kota tersebut memiliki skala produksi industri rumah tangga, kecil, dan menengah. Menjadi suatu hal yang menarik melihat persebaran dan dinamika industri batik dengan cara produksi tradisional di Bandung, Cirebon, dan Tasikmalaya berkembang pada saat Indonesia mengalami masa industrialisasi selama Orde Baru. Penelitian ini menunjukkan terjadinya pasang-surut industri batik tradisional di tengah-tengah gempuran modernisasi di bidang industri, tidak terkecuali dalam tekstil lokal.
\end{abstract}

Kata Kunci: industri, batik, Bandung, Cirebon, Tasikmalaya

\begin{abstract}
The study used the historical method which included a number of stages, such as heuristics, criticism, interpretation, and historiography and also applied a socio-economic approach to explain chronologically the effect of the distribution of the batik industry on the welfare of the people of Bandung, Cirebon, and Tasikmalaya. The sample is used in this study to find and collect data. The results of literature study, field studies, observations, and interviews have revealed that the spread of batik culture has had a significant effect on the emergence of the batik industries in Bandung, Cirebon, and Tasikmalaya. The batik industries in the three regions has played an important role in creating jobs for local communities who have the expertise in doing the batik work, both the 'batik tulis' and the 'batik cap'. In addition, the batik industry in the three cities also has the industrial productions which includes either the household or small to medium scale. It is an interesting fact to see the distribution and the dynamics of the batik industry were produced through traditional production methods in Bandung, Cirebon and Tasikmalaya when Indonesia was experiencing a period of industrialization during the New Order. The research has shown that
\end{abstract}


there have been ups and downs in the traditional batik industry amidst the threat of modernization in the industrial sector, including local textiles.

Keywords: industry, batik, Bandung, Cirebon, Tasikmalaya

\section{A. PENDAhuluaN}

Industri batik merupakan salah satu bentuk etnopreneurship; jenis wirausaha yang dilatarbelakangi oleh identitas suku yang dimiliki oleh masyarakat pribumi pada masa kolonial Belanda (1800-1942) dan Jepang (1942-1945). Lebih jauh sebelum itu, pada masa Kesultanan Mataram berkuasa (1587-1677) dan mengalami keruntuhan serta kemudian lahir Kasunanan Kartasura (1680-1742) sebagai ahli waris Kesultanan Mataram (Achmad, 2016: 229), tradisi membatik sudah menjadi budaya keraton yang dilestarikan turun-temurun. Tradisi membatik sudah dilakukan sejak Mataram Islam hingga lahirnya Kasunanan Surakarta dan Kasultanan Yogyakarta akibat perjanjian Giyanti.

Bermula sebagai budaya di lingkungan keraton kemudian menyebar ke masyarakat umum, lambat laun budaya membatik tidak lagi bersifat eksklusif milik keluarga keraton/kerajaan (Boow, 1988). Sejak saat itu membatik menjadi suatu hal yang lumrah dilakukan oleh masyarakat umum di Pulau Jawa sebagai akibat dari hegemoni Kesultanan Mataram di sebagian besar Pulau Jawa sebelum masa kolonialisme Vereenigde Oost Indische Compagnie (VOC).

Kain batik kemudian mulai diperjualbelikan secara terbatas dan memiliki nilai jual yang cukup tinggi di pasaran. Merembesnya pengaruh ekonomi (kapitalisme) kolonial Belanda pada seluruh lapisan masyarakat mengakibatkan tradisi membatik bertransformasi menjadi industri yang menghasilkan komoditas dagangan kain batik yang diminati oleh berbagai kalangan elite Pribumi, Timur Asing (Cina, Arab, India, dan lain-lain) (Permanasari \& Cahanar, 2019). Bahkan, orang-orang Eropa pun kemudian tertarik dengan batik sebagai suatu bahan pakaian maupun sebatas barang koleksi yang antik dan unik dari negeri jajahan.

Persebaran dari industri batik skala rumah tangga pada awal perkembangannya mengalami pertumbuhan yang pesat seiring dengan semakin meningkatnya jumlah permintaan di pasar terhadap batik. Terutama setelah lahirnya segolongan pribumi terdidik (kelas menengah) yang berstatus sebagai pegawai pemerintah kolonial (Inlandsche Bestuur) akibat dari kebijakan Politik Etis yang diterapkan pada awal abad ke-20 di Hindia Belanda (Prananta, 2019).

Apabila ditelaah lebih jauh di Jawa Barat industri batik mulai tumbuh dan menyebar secara berkelanjutan dari dua wilayah. Pesisir Pantai Utara (Cirebon dan Indramayu) dan wilayah Pegunungan di Selatan Jawa Barat (Tasikmalaya). Daerah Cirebon dan Indramayu membawa batik dengan motif khas pesisiran sedangkan Tasikmalaya membawa batik dengan motif khas pedalaman (Trade Research \& Development Agency, 2008).

Memasuki periode kemerdekaan Indonesia ketiga daerah di atas menjadi pusat budaya batik Jawa Barat, sekaligus menjadi pusat perkembangan industri batiknya. Namun, pada periode Orde Baru (1967-1998) persebaran industri batik di Jawa Barat mulai bertambah dengan adanya industri batik di Bandung ditandai dengan lahirnya Hasan Batik's (1975) milik Hasanuddin seorang dosen Fakultas Seni Rupa dan Desain (FSRD), Institut Teknologi Bandung (ITB).

Industri batik di Bandung, Cirebon, dan Tasikmalaya pada perkembangannya menjadi tulang punggung perekonomian masyarakat daerah setempat. Oleh karena itu, dinamika usahanya pun berpengaruh terhadap tingkat kesejahteraan masyarakat yang menggantungkan hidupnya kepada industri tersebut. 
Maka dari itu, membahas industri batik bukan hanya berbicara mengenai kesejahteraan para perajinnya dan nilainilai estetik dari batik. Di balik keindahan yang dimiliki selembar kain batik menyimpan berbagai mitos, cerita, dan sejarah perjalanan suatu bangsa. Hal ini terlihat dari banyaknya literatur yang membahas batik. The Dancing Peacock Colours and Motifs of Priangan Batik (2010) karya Didit Pradito dkk, misalnya merupakan buku yang mengulas warna dan motif batik dari Priangan yang mencakup (Ciamis, Tasikmalaya, dan Garut). Buku Saku Batik Jawa Barat (2009) karya S. Ken Atik, dkk. Buku Saku Batik Jawa Barat Jilid II (2010) karya S. Ken Atik, dkk. Buku Batik Jawa Barat Jilid III (2013) karya S. Ken Atik, dkk, dan Batik Eksistensi untuk Tradisi (2011) karya Komarudin Kudiya. Adapun karya Justine Boow (1988), Symbol and Status in Javanese Batik, membahas nilai-nilai simbol dan status suatu motif dalam batik Jawa (Surakarta dan Yogyakarta).

Konsep-konsep yang digunakan dalam penelitian ini adalah persebaran, batik, dan industri. Penelitian ini bertujuan untuk mengetahui bagaimana persebaran budaya membatik dan perkembangan industri batik serta pengaruhnya terhadap kesejahteraan masyarakat di tiga daerah Bandung, Cirebon, dan Tasikmalaya $1967-$ 1998.

Apabila kita mengikuti pemikiran evolusionis dari E.E. Bergel tentang alur perkembangan kota sebagai sebuah ruang yang pada awalnya adalah sebuah desa yang mengalami perubahan terus-menerus menjadi sebuah kota (Basundoro, 2016: 1). Hal yang sama dilakukan penulis terhadap Bandung, Cirebon, dan Tasikmalaya merupakan bagian integral dari konsep mengenai ruang dalam melihat persebaran (migrasi) penduduk.

Menurut Kusmayanto sebagaimana dikutip oleh Kudiya (2011: 9) kata batik itu merupakan gabungan dari dua kata dalam bahasa Jawa yaitu amba (padanan kata menulis) dan titik. Selain itu, ada yang menuturkan bahwa batik adalah paduan dua kata tiba (tiba dalam bahasa Jawa artinya jatuh) dan titik.

Raymond Aron dalam The Industrial Society menyatakan hanya ada satu bentuk masyarakat industrial, perbedaan antara sistem-sistem sosial, baik sosialisme maupun kapitalisme tidak lagi berarti (Kuntowijoyo, 2018: 162).

\section{B. METODE PENELITIAN}

Penelitian ini menggunakan metode sejarah yang memiliki empat tahapan kerja. Pertama, heuristik adalah proses pengumpulan sumber primer dan sekunder. Kedua, kritik internal dan eksternal. Ketiga, interpretasi. Keempat, historiografi.

Sumber-sumber yang digunakan terdiri dari laporan penelitian, artikel ilmiah dan populer, skripsi, buku, peta, sumber daring (website), observasi, dan wawancara. Pendekatan penelitian yang digunakan adalah multidisiplin dengan penyusunan secara kronologis-tematik untuk memudahkan pembaca melihat perubahan yang terjadi.

\section{HASIL DAN BAHASAN}

\section{Sebaran Pengaruh Budaya Membatik di Jawa Barat}

Pada akhir abad ke-19 Jawa Barat terbagi atas lima keresidenan, yaitu Batavia (Jakarta), Bantam (Banten), Krawang (Karawang), Priangan (Sukabumi, Cianjur, Bandung, Sumedang, Garut, dan Tasikmalaya) serta Cheribon (Indramayu, Cirebon, Majalengka, Kuningan, dan Galuh/Ciamis) (Verbeek, \& Fennema, 1896). Masing-masing wilayah administrasi pemerintahan tersebut diperintah oleh seorang Residen yang dibantu oleh seorang Asisten Residen dan bertanggung jawab kepada Gubernur Jenderal (Mulyana, 2018: 13).

Secara geografis wilayah Jawa Barat dibagi menjadi dua bagian sebelah utara merupakan daerah dataran rendah sering disebut Pantura (Pantai Utara), sedangkan sebelah selatan merupakan daerah dataran 
tinggi atau daerah pegunungan, dengan perbandingan (1:3). Hal ini membuktikan bahwa daerah Jawa Barat didominasi oleh dataran tinggi dan orang-orang luar Jawa Barat sering menyebut orang Jawa Barat bagian selatan (Priangan) sebagai "orang gunung" (Mulyana, 2018: 14).

Sunda merupakan sebutan bagi masyarakat asli yang tinggal di Jawa Barat. Namun, tidak semua wilayah yang termasuk dalam administrasi Provinsi Jawa Barat, penduduknya berbahasa Sunda seperti Cirebon. Hal ini dilatarbelakangi oleh sebagian besar penduduknya berasal dari Jawa Tengah (Mulyana, 2018: 14).

Dalam struktur kehidupan masyarakat Sunda tradisional dikenal dua kelompok masyarakat. Pertama, kelompok elite atau biasa disebut "menak" dan kedua, masyarakat biasa yang disebut "jalma leutik" atau "cacah" (Mulyana, 2018: 18).

Masyarakat Jawa Barat baik daerah pesisiran maupun pedalaman, tentu memiliki keanekaragaman corak tradisi yang berbeda sesuai dengan budaya, ekologi, dan sejarah tempat masyarakat itu berada serta berkembang. Kemudian, tiga hal itu lah yang akan membentuk identitas suatu masyarakat.

Menurut Dedy Mulyana (2001: 18) dalam (Warsito, 2017: 49) budaya adalah daya dari budi, yang berupa cipta, rasa, dan karsa; sedangkan kebudayaan adalah hasil dari cipta, rasa dan karsa. Budaya secara formal didefinisikan sebagai tatanan pengetahuan, pengalaman, kepercayaan, nilai, sikap, makna, hierarki, waktu, peranan, hubungan ruang, konsep alam semesta, objek-objek materi dan milik yang diperoleh sekelompok besar orang dari generasi ke generasi melalui usaha individu dan kelompok.

Menurut Koentjaraningrat (1999: 109) dalam (Warsito, 2017: 53) budaya sebagai suatu kompleks dari ide-ide, gagasan, nilai-nilai, norma-norma, peraturan, wujud kebudayaan yang pertama kemudian bertransformasi menjadi wujud kebudayaan sebagai suatu aktivitas serta tindakan berpola dari manusia dan sekelompok manusia dalam masyarakat, wujud kebudayaan yang pertama dan kedua masih bersifat tak benda. Ketiga menjadi wujud kebudayaan yang berupa benda-benda hasil karya manusia seperti kain batik.

Kain batik adalah salah satu wujud representasi dari kebudayaan suatu bangsa, dalam hal ini masyarakat Jawa yang umum diketahui sebagai pengembang awal budaya membatik di Pulau Jawa. Kemudian diikuti oleh masyarakatmasyarakat lain, salah satunya masyarakat Sunda. Budaya membatik dalam masyarakat Sunda di Jawa Barat adalah suatu cara melanggengkan pengalaman hidup yang berupa hasil cipta, rasa, dan karsa generasi tua kepada generasi muda.

Batik cloths do act as signs in Javanese society in a straightforward way. There are rules and practices governing the use of cloths and patterns which are understood by many people to signify relative status, maintain "harmony" and develop gradations of hierarchy (Boow, 1988: 9).

Pakaian Batik berperan sebagai lambang dalam masyarakat Jawa dengan cara mengikuti pakem. Terdapat sejumlah aturan dalam penggunaan batik dan pola-pola yang dipahami oleh banyak orang untuk menandakan status keluarga, mempertahankan harmoni dan mengembangkan gradasi hierarki (Boow, 1988: 9).

Menurut Ajip Rosidi sebagaimana dikutip oleh Sunarya (2010: 6), di dalam naskah buhun" Sunda - "Sanghyang Siksa Kandang Karesian" awal abad ke-16 yang berkenaan dengan artefak batik, terdapat fakta disebutnya bermacam-macam corak lukisan (tulis): pupunjengan, hihinggulan, kekembangan, alas-alasan, urangurangan, memetahan, sisirangan, taruk hata, kembang tarate, disebut juga

${ }^{1}$ Buhun bermakna sesuatu yang sudah tua. 
beragam kain (boeh): kembang $m u(\mathrm{n})$ cang, gagang senggang, anyam cayut, poleng re(ng)ganis, cecempaan, mangin haris, surat awi, parigi nyengsoh, hujan riris; yang menunjukkan bahwa pada naskah itu ditulis, orang Sunda telah mengenal berbagai corak kain (samping) batik. Walaupun tidak ada peninggalan dari Kerajaan Sunda Padjadjaran, namun ditemukan kain berusia 200-300 tahun.

Memperkuat pernyataan sebelumnya, berdasarkan hasil temuan para filolog naskah Sanghyang Siksa Kandang Karesian ditulis pada 1440 Saka atau 1518 M tepatnya pada masa kepemimpinan Prabu Guru Darmasiksa. Naskah ini berisi mengenai keadaan sosial-kemasyarakatan, sosial-budaya, agama, dan pemerintahan Kerajaan Sunda Padjadjaran (Salam, 2017). Naskah ini menjadi bukti bahwa ada proses akulturasi budaya antara Sunda dan Jawa baik melalui proses perdagangan maupun perkawinan seperti tercermin dalam berbagai motif batik, sebelum adanya invasi hegemoni Kesultanan Mataram ke wilayah Priangan pada masa sesudah runtuhnya Kerajaan Sunda Padjadjaran (1579). Saat itu, wilayah Priangan berada di bawah kekuasaan Kerajaan Sumedanglarang (1580-1620) penerus trah Kerajaan Sunda Padjadjaran (Katam, 2014: 9).

Menyoal tradisi membatik di Jawa Barat, akar historisitas dan kebudayaannya dapat dilacak hingga pada awal masa kekuasaan Kesultanan Mataram di bawah kepemimpinan Sultan Agung Senapati ing Ngalaga atau Sultan Abdullah Muhammad Maulana Mataram (1613-1645). Kesultanan Mataram melakukan berbagai ekspedisi militer untuk menaklukan daerah-daerah di bagian timur Wirasaba (1615), Lasem dan Pasuruhan (1616), Madura, Sukadana, dan Surabaya (1624) serta Blambangan (1640); di bagian barat ada Batavia yang diduduki oleh VOC; dan Priangan berada di bawah Kerajaan Sumedanglarang yang menyatakan tunduk kepada Mataram pada 1620. Mataram tidak berusaha menundukkan Kesultanan
Cirebon karena menghormati Sunan Gunung Jati sebagai salah satu guru Sultan Agung sekaligus seorang penyebar Islam di Jawa bagian kulon. Ekspedisi-ekspedisi militer di Pulau Jawa dan sekitarnya bertujuan untuk menegakkan supremasi dan hegemoni Kesultanan Mataram di tanah Jawa (Achmad, 2016).

Adanya ekspedisi ke bagian barat dan timur Pulau Jawa dan Madura, menandai adanya penyebaran tradisi membatik dari pusat kekuasaan Kesultanan Mataram ke berbagai daerah yang ditaklukkannya tidak terkecuali Jawa bagian kulon sebutan lain untuk Jawa Barat. Pada perkembangannya Cirebon dan Indramayu menjadi pusat penyebaran budaya membatik di Jawa Barat bagian utara sedangkan Tasikmalaya menjadi pusat penyebaran yang kokoh di daerah pegunungan selatan Jawa Barat.

Dalam kajian budaya proses penyebaran budaya di atas, termasuk ke dalam bagian dari hegemoni budaya dan turunannya akulturasi dan difusi. Budaya penguasa (Mataram) secara sadar disebarkan di daerah-daerah kekuasaannya. Cepat atau lambat budaya penguasa tadi akan menjadi bagian dari budaya masyarakat yang dikuasainya, daerah Bandung, Sumedang, Indramayu, Cirebon, Garut, Tasikmalaya, dan Ciamis adalah daerah yang terhegemoni oleh budaya Mataram, salah satunya membatik.

Proses penyebaran budaya membatik disebarkan oleh masyarakat Jawa yang berdiaspora di bawah otoritas Kesultanan Mataram ke Jawa bagian kulon, secara tidak langsung melalui proses migrasi temporer yang berubah secara permanen untuk sebagian Pasukan Kesultanan Mataram yang hendak menaklukkan Kesultanan Banten yang sebelumnya harus berhadapan dengan VOC di Batavia. Hal ini disebabkan VOC yang menolak tawaran damai Kesultanan Mataram yang diwakili Kyai Rangga (Bupati Tegal) sehingga memicu ekskalasi konflik yang luas di ujung barat Pulau Jawa (Achmad, 2016: 226). 


\begin{abstract}
Gelombang serangan pertama Kesultanan Mataram dimulai pada 27 Agustus 1628 di bawah komando Tumenggung Bahureksa. Gelombang selanjutnya dimulai pada Oktober 1628 di bawah komando Pangeran Mandurareja. Gelombang serangan kedua dilancarkan Pasukan Mataram I di bawah kepemimpinan Adipati Ukur pada Mei 1629, disusul oleh Pasukan Mataram II di bawah komando Adipati Juminah pada Juni 1629 (Achmad, 2016: 226).
\end{abstract}

Proses diaspora masyarakat Jawa ke Priangan pasca perang melawan VOC didukung oleh perdagangan dan perkawinan dengan penduduk setempat, mengakibatkan proses penyebaran dan peresapan unsur-unsur budaya pendatang diterima tanpa paksaan serta berjalan cepat. Proses tersebut adalah penetration pasifique (Warsito, 2017).

Beberapa ratus tahun kemudian hubungan antara wilayah Pantura Jawa Barat (Indramayu dan Cirebon) serta Priangan dan Surakarta-Yogyakarta lebih lancar dengan berkembangnya sentra batik di Pesisir Utara Jawa Tengah (Pekalongan) disertai peningkatan volume perdagangan pasca pembangunan Jalan Raya Pos (Anyer-Panarukan) sejauh $1.000 \mathrm{~km}$ pada masa kepemimpinan Gubernur Jenderal H.W. Daendels (1808-1811) (Katam, 2014).

Menurut sensus penduduk tahun 1930, di wilayah Jawa Barat terdapat penduduk 8.275.140 orang yang termasuk suku bangsa Sunda. Jumlah seluruh penduduk di wilayah ini, terdiri atas 5.586 .999 orang pria dan 5.810 .147 orang wanita atau terdiri atas 11.039 .350 orang Indonesia dan 80.774 orang Eropa, 259.718 orang Cina, dan 17.304 orang Timur Asing lainnya terutama orang $\mathrm{Arab}^{2}$. Jika dipresentasikan, perbandingan orang Indonesia yang tinggal di Jawa Barat waktu itu adalah $75 \%$ orang Sunda, $16 \%$ orang Jawa, $8,65 \%$ orang Betawi (Mulyana, 2018: 14).

Berdasarkan data di atas proses akulturasi dan difusi budaya antara Sunda dan Jawa telah berjalan cukup lama, indikasinya presentase masyarakat pribumi di Jawa Barat selain masyarakat aslinya, kedua terbesar adalah etnis Jawa dan diikuti oleh etnis Betawi yang terkonsentrasi di daerah Jakarta sekarang.

Memasuki dekade-dekade awal kemerdekaan Indonesia presentase etnis Jawa di Provinsi Jawa Barat cenderung meningkat dari setiap sensus ke sensus. Peningkatan ini didorong oleh semakin derasnya proses industrialisasi yang mengakibatkan terjadinya urbanisasi.

\section{Industrialisasi Tekstil}

Industrialisasi di Indonesia secara umum terdapat dua jenis industri yang berkembang. Pertama, industri rakyat berskala rumah tangga dan kecil yang dikerjakan secara manual dengan menggunakan keterampilan tangan pekerja (handmade). Industri semacam ini sudah ada jauh sebelum penyerahan seluruh wilayah Nusantara yang dikuasai oleh VOC kepada Pemerintah kolonial Belanda pada 1800. Kedua, industri modern yang dikerjakan secara massal dengan pengerjaannya dibantu mesin-mesin modern (manufacture) (Basundoro, 2016: 188). Industri batik di Indonesia ada yang menjalankan produksinya secara tradisional maupun modern. Industri modern yang melakukan mekanisasi produksi batik, mesin-mesin inilah yang menggantikan tangan terampil para perajin batik tulis dan cap.

Selama masa Pendudukan Pemerintah Militer Jepang (1942-1945) di Indonesia, aktivitas ekonomi dalam bidang sandang terutama industri batik tidak berjalan seperti biasanya. Di masa itu, kondisinya berubah 180 derajat hingga ratusan usaha batik tutup dan baru kembali bangkit setelah Indonesia merdeka (Permanasari \& Cahanar, 2019: 134).

${ }^{2}$ Volkstelling, (1930), I. 
Beberapa tahun setelah Indonesia merdeka, Pemerintah RI memutuskan untuk membangun perekonomian negara dengan menggunakan pendekatan ekonomi kerakyatan seperti yang dicetuskan oleh Mohammad Hatta (Wakil Presiden RI yang Pertama) salah satunya dengan sistem koperasi yang berasal dari bahasa Latin "coopere" yang artinya bekerja sama. Koperasi awal-mulanya tumbuh tahun 1950-an, salah satunya dengan terbentuknya Gabungan Koperasi Batik Indonesia (GKBI). Peranan GKBI mulai dapat menggantikan kedudukan pengusaha-pengusaha Tionghoa yang mendapat keistimewaan selama masa kolonialisme Belanda (1800-1942) untuk menjadi pengusaha selain kaum pribumi yang dibatasi peranannya dalam sektor perdagangan (Noer, 2015: 143).

Imbas dari kebijakan pembangunan berbasis ekonomi kerakyatan adalah industrialisasi di Indonesia secara umum berjalan lambat, karena aliran modal untuk membangun negara yang porak-poranda pasca Agresi Militer Belanda ke-1 (1947) dan 2 (1949) serta pemberontakanpemberontakan di berbagai daerah di dalam negeri memperlambat kinerja kabinet untuk memulihkan kondisi perekonomian negara.

Memasuki masa Demokrasi Parlementer (1950-1957), Indonesia belum memiliki kemampuan untuk melaksanakan pembangunan ekonomi (industrialisasi) di berbagai sektor penting. Sejauh ini, pemerintah baru menempuh langkahlangkah berupa rehabilitasi struktur perekonomian dan penanggulangan kesulitan keuangan (Leirissa, Ohorella, dan Tangkilisan, 2012: 91).

Berganti sistem pemerintahan dari Demokrasi Parlementer ke Demokrasi Terpimpin (1958-1966) tidak membuat perekonomian Indonesia menjadi lebih baik, justru pada saat Demokrasi Terpimpin Indonesia masuk ke dalam jurang inflasi dan krisis ekonomi terparah sepanjang sejarah.
Memasuki masa Orde Baru (19671998), Indonesia menerapkan kebijakan Pembangunan Jangka Panjang (25 tahun) dan Rencana Pembangunan Lima Tahun (Repelita) I-VI yang bertujuan salah satunya untuk menciptakan stabilitas politik dan ekonomi sebagai syarat untuk pelaksanaan dan keberhasilan repelita, pemilihan umum, dan merumuskan serta melaksanakan rencana strategis repelita (Leirissa, Ohorella, dan Tangkilisan, 2012: 99).

Awal kekuasaan rezim Orde Baru, Indonesia sering disebut sebagai salah satu negara pasca-kolonial yang memiliki pertumbuhan ekonomi yang tinggi dengan corak agraris dan semi-industri di Asia. Hal ini tidak terlepas dari peranan sebuah tim yang dibentuk Soeharto pada 15 Juni 1968 terdiri dari para teknokrat (teknisibirokrat) berlatar belakang pendidikan barat. Hasil pemikiran para pakar itu diterjemahkan ke dalam bentuk repelita (Leirissa, Ohorella, dan Tangkilisan, 2012: 99-100).

$$
\begin{aligned}
& \begin{array}{l}
\text { Dengan ekonomi berencana } \\
\text { (repelita)...kemudian dicapai }
\end{array} \\
& \text { kemajuan. Secara makro boleh } \\
& \text { dibilang sukses. Pertumbuhan } \\
& \text { ekonomi rata-rata } 6 \% \text { setahun. Dan } \\
& \text { juga yang menarik adalah } \\
& \text { berkurangnya mereka yang berada } \\
& \text { di bawah garis kemiskinan dari } 54 \\
& \text { juta tahun } 1976 \text { menyusut menjadi } \\
& 27 \text { juta pada } 1990 \text { (Tempo, 1993: } \\
& \text { 12). }
\end{aligned}
$$

Lahirnya repelita membawa dampak ekonomi yang cukup signifikan karena fokus pembangunan negara yang berorientasi meningkatkan kesejahteraan masyarakat, lebih terukur, dan jelas target capaiannya. Pada masa ini, iklim investasi sangat didukung dengan diberikannya ruang untuk mengakselerasi pertumbuhan industri dengan beberapa kebijakan seperti perombakan sistem devisa yang mana transaksi luar negeri menjadi lebih bebas dan disederhanakan agar bahan baku dan modal tidak sukar diperoleh. Contohnya kain dan zat pewarna yang diperlukan oleh 
pengusaha-pengusaha batik yang tidak tersedia dari dalam negeri di impor dan terbentuknya Inter-Governmental Group on Indonesia (IGGI) yang memberikan pinjaman jangka panjang untuk proses pembangunan dalam negeri (Leirissa, Ohorella, dan Tangkilisan, 2012: 101).

Industri batik di Indonesia umumnya merupakan industri rumah tangga, kecil, dan menengah (UMKM) yang menjadi mata pencaharian utama sebagian besar masyarakat di daerah pinggiran kota (Nurainun, H \& Rasyimah, 2008: 124). Menurut Indi Sutopo (2011: 103) keberadaan usaha (UMKM) di Indonesia adalah penting dengan beberapa alasan (Beery, 2001); sebagai sumber potensial dalam menciptakan lapangan kerja, memacu pertumbuhan ekonomi, sebagai sumber produksi subtitusi impor barang konsumsi yang murah dan diperolehnya devisa melalui ekspor. Industri batik mengalami pertumbuhan terutama setelah diberlakukannya Undang-Undang Penanaman Modal Asing (UU PMA) dan Undang-Undang Penanaman Modal dalam Negeri (UU PMDN) masing-masing diberlakukan pada 1967 dan 1968.

Menurut Leirissa, Ohorella, dan Tangkilisan (2012: 103), pencanangan undang-undang penanaman modal asing dan penanaman modal dalam negeri dimaksudkan untuk menumbuhkan industri-industri baru yang dapat mengurangi perbedaan (kesenjangan) antar daerah. Namun, angka-angka Badan Koordinasi Penanaman Modal (BKPM) menunjukkan bahwa $70 \%$ proyek industri yang direkomendasikannya berlokasi di Pulau Jawa, salah satunya Provinsi Jawa Barat.

Jawa Barat pada masa Orde Baru memiliki jumlah angkatan kerja yang besar namun jumlah lapangan pekerjaan yang tersedia sangat terbatas, hal inilah yang mengakibatkan Jawa Barat memiliki upah pekerja yang rendah. Alasan ini memungkinkan Jawa Barat menjadi surga bagi para pemilik perusahaan asing dan dalam negeri yang berorientasi pada "labour intensive".

[...] kebanyakan perusahaan tekstil dan pakaian jadi, buruh di perusahaan ini bekerja dengan jam kerja yang panjang dan upah yang rendah. Dibagi dalam tiga shift ${ }^{3}$, proses kerja (produksi) berlangsung 24 jam tanpa henti. Artinya, tanpa lembur, seorang buruh per shift bekerja selama tujuh jam sehari atau 40 jam seminggu (upah dibayar mingguan). Terdapat pula non-shift, yakni buruh perawatan yang bekerja setiap hari pukul $08.00-16.00$ (Djajusman, 1993: 52).

Fenomena ini akan bertahan selama perpaduan yang tidak berimbang antara jumlah pekerja yang terus meningkat dan fasilitas-fasilitas lapangan pekerjaan yang berkembang lamban (Tempo, 1971). Alasan di atas dibuat oleh pihak manajemen untuk menjamin kelancaran produksi dari pabrik tersebut, melalui berbagai kontrol, tertulis maupun lisan, formal maupun informal serta tidak ada pilihan lain bagi tenaga kerja (buruh) kecuali tunduk pada disiplin perusahaan yang berorientasi mengejar keuntungan bagi pengusaha dan investor dalam dan luar negeri (Djajusman, 1993).

\section{Industri Batik di Bandung}

Industri batik di Bandung apabila dipetakan dalam kontestasi dunia perbatikan di Jawa Barat bisa dikatakan tidak ada sama sekali, besar kemungkinan mengapa di Bandung tidak terdapat perajin batik atau bahkan industri batik dilatarbelakangi oleh kuatnya pengaruh budaya Indische (campuran) antara gaya hidup pribumi dan Belanda. Sejak masa pemerintahan Wiranatakusumah IV, ibu kota Keresidenan Priangan dipindahkan ke Bandung dari Cianjur berdasarkan besluit No. 18 tanggal 17 Agustus 1864 (Katam, 2014: 15).

\footnotetext{
${ }^{3}$ Pagi (06.00 - 14.00), Siang (14.00 - 22.00) dan Malam (22.00 - 06.00)
} 
Konsekuensi logis dari berpindahnya Ibu Kota Keresidenan Priangan ke Bandung adalah semakin banyaknya orang Belanda yang tinggal menetap di Bandung terutama para Binenland Bestuur yang menyertai tugas seorang Residen. Meskipun, Bandung dikenal dengan sebutan "Parijs van Java" yang menunjukkan sifat metropolisnya setelah Gubernur Jenderal van Heutz menetapkan status Bandung (Ibu Kota Kabupaten) menjadi Gemeente (Pemerintah Kota) pada 1 Maret 1906 (Katam, 2014: 16). Tetapi kelompok menak (penguasa) dari kalangan pribumi (Bupati/Patih/Wedana dst) tetap memegang adat kebiasaan berpakaian layaknya seorang menak menggunakan jas kurung dan sarung batik.

Memasuki tahun 1975 di Kota Bandung terdapat industri batik skala rumah tangga milik seorang migran asal Pekalongan yang bekerja sebagai Dosen di FSRD ITB. Nama perusahaannya Hasan Batik's, sesuai dengan nama pemiliknya Hasanuddin. Hasanuddin lebih sering dipanggil Hasan, beliau adalah seorang putra daerah yang berasal dari sebuah kota yang memiliki julukan kota batik dan mempunyai budaya batik pesisiran yang sangat terkenal sepanjang pantura (Sari, wawancara, 9 September 2019). Selain itu, orang pantura juga dikenal dengan mobilitasnya yang tinggi.

Kedatangan Hasan sewaktu muda ke Bandung dilatarbelakangi oleh motif ekonomi dan pendidikan. Dua daya tarik untuk bermigrasi terutama bagi para pemuda, menurut Dorothy Thomas dalam (Lee, 1976: 4) dan kawan-kawannya berkesimpulan bahwa satu-satunya generalisasi yang dapat dibuat mengenai diferensial untuk migrasi dalam negeri bahwa migrasi itu kebanyakan dilakukan oleh remaja yang paling tua berumur 19 tahun. Hal ini senada dengan yang dilakukan Hasan muda untuk bermigrasi ke Bandung selepas lulus SLTA, keadaan ini turut dipengaruhi oleh keadaan sosialekonomi di Pekalongan.
Banyak perusahaan batik gulung tikar antara lain disebabkan pasaranpasaran seperti Jepang dan Singapura telah berhasil memproduksi batik sendiri secara lebih cepat dan murah. Disamping rongrongan pajak yang konon dirasakan terlalu menghambat, intervensi perjudian (lotere buntut) juga memperlemah daya tahan pengusaha batik yang memang sudah tidak begitu kuat lagi (Tempo, 1971: 19).

Akumulasi alasan-alasan di atas semakin memperkuat Hasan muda untuk melakukan migrasi, "pedagang-pedagang batik meninggalkan usahanya dan meloncat ke bidang lain seperti perusahaan pangan, perhotelan atau pindah keluar kota dan berusaha di sana" (Tempo, 1971: 19).

Hasan muda adalah salah satu anak keluarga perajin batik yang memutuskan migrasi temporer ke Bandung, sebelum nantinya memutuskan untuk migrasi secara permanen.

Penulis berpendapat motif Hasan muda untuk menuntut ilmu di Bandung selain menjadi kota pusat pendidikan tinggi di Jawa Barat, alasan lainnya adalah tingkat pertumbuhan ekonomi daerah tersebut cukup pesat. Selain itu, daya beli masyarakatnya pun rata-rata lebih tinggi dibandingkan di daerah Jawa Tengah.

Berbagai alasan tadi mendukung konsep migrasi dan jarak "migran yang menempuh jarak yang jauh umumnya lebih suka menuju ke pusat-pusat perdagangan dan industri yang penting" (Lee, 1976: 2). Bandung pada saat itu merupakan pusat perekonomian terbesar di Jawa Barat sehingga menarik minat para pemuda untuk melakukan urbanisasi dalam rangka meningkatkan kesejahteraan.

Bakat dan minatnya terhadap seni, tidak bisa dilepaskan dari unsur ikatan kebudayaan. Ikatan kebudayaan adalah suatu karya tidak terlepas dari lingkungan tempat kebudayaannya berasal. Daerah asalnya (Pekalongan) merupakan daerah yang sudah berabad-abad lamanya menjadi 
sentra batik pesisiran di Pantai Utara Jawa Tengah. Batik juga dikenal sebagai salah satu warisan budaya masyarakat di Pulau Jawa baik di daerah vorstenlanden (Kasunanan Surakarta, Kadipaten Mangkunegaran, Kesultanan Yogyakarta, dan Kadipaten Pakualaman) maupun di daerah Pesisir Utara Pulau Jawa (Indramayu, Cirebon, Pekalongan, Lasem, Tuban dan lain-lain). Jadi bukan suatu kebetulan jika Hasan menjadi seorang pengusaha batik berbakat dan ternama di Kota Bandung.

Saat memutuskan untuk pergi ke Bandung dan melanjutkan pendidikan di di FSRD ITB, Hasan muda sudah menekuni dunia seni batik jauh sebelum kedatangannya ke Bandung. Hal ini juga yang memotivasinya untuk membuka usaha batik dengan merek dagang Hasan Batik's yang kelak dikenal luas di pasaran lokal dan mancanegara, disebabkan inovasinya dalam pengembangan motif batik tambal sulam (patchwork) adalah motif batik yang didasarkan pada pola berulang yang menjadi ciri khas dari Hasan Batik's (Sari, wawancara, 9 September 2019).

Hasan Batik's pada mulanya beralamat di daerah Muararajeun, sebelum pindah ke Cigadung pasca terjadinya kebakaran di rumah, industri batik, dan gudang penyimpanannya yang masih dalam satu lingkup kawasan. Akibat dari kebakaran itu peralatan dan hampir semua stok batik yang tersedia di gudang serta peralatan membatik habis tak bersisa, begitu pula dengan berbagai surat-surat berharga, catatan administrasi, dan keuangan usaha pun tidak ada yang bisa diselamatkan (Sari, wawancara, 9 September 2019).

Hasan Batik's kemudian pindah ke Kelurahan Cibeunying, Desa Cigadung, Bandung akibat kebakaran yang menimpa pabrik dan rumahnya. Tempat workshop dan rumah baru di Cigadung selesai dibangun pada awal 1990-an. Semua proses produksi Hasan Batik's, tempat kursus membatik, dan outlet penjualannya pun semenjak itu sudah di Cigadung (Sari, wawancara, 9 September 2019).

Tabel 1. Kondisi Pekerja Hasan Batik's Tahun 1975-1998

\begin{tabular}{|c|c|c|c|}
\hline Tahun & $\begin{array}{l}\text { Jumlah } \\
\text { Pekerja }\end{array}$ & $\begin{array}{l}\text { Rata- } \\
\text { rata } \\
\text { Usia }\end{array}$ & $\begin{array}{c}\text { Rata-rata } \\
\text { Pendidikan }\end{array}$ \\
\hline 1975 & 5 & \multirow{6}{*}{$\begin{array}{l}12-55 \\
\text { Tahun }\end{array}$} & \multirow{3}{*}{$\begin{array}{c}\text { SLTP } \\
\text { Sederajat }\end{array}$} \\
\hline 1980 & 10 & & \\
\hline 1985 & $10-15$ & & \\
\hline 1990 & 20 & & \multirow{3}{*}{$\begin{array}{c}\text { SLTA } \\
\text { Sederajat }\end{array}$} \\
\hline 1995 & $>20$ & & \\
\hline 1998 & $<10$ & & \\
\hline
\end{tabular}

Sumber: Wawancara dengan Sania Sari. 37

Tahun. General Manager Studio Hasan

Batik's. 9 September 2019 di Studio Hasan Batik's, Kota Bandung.

Tingkat daya serap tenaga kerja Hasan Batik's sebagai industri rumah tangga-kecil, tidak terlalu berperan dalam membuka lapangan pekerjaan bagi masyarakat di daerah sekitarnya (Muararajeun dan Cigadung). Hal ini tentu dibatasi oleh keterbatasan modal, daya saing produk, dan ketersediaan pasar di Bandung. Namun, tingkat kesejahteraan para perajin relatif sejahtera karena besaran upah yang diterima cukup untuk memenuhi kebutuhan dasar dan mayoritas konsumen Hasan Batik's dari kalangan menengah ke atas yang memiliki kemampuan daya beli tinggi (Sari, wawancara, 9 September 2019).

\section{Industri Batik di Cirebon}

Berbicara mengenai peta persebaran budaya dan industri batik di Jawa Barat, Cirebon adalah episentrum di bagian utaranya. Secara geografis Cirebon berbatasan secara langsung dengan daerah Jawa, salah satunya Tegal, tetangga Pekalongan sebuah daerah yang dijuluki kota batik di Pesisir Utara Jawa Tengah.

Cirebon secara budaya lebih kuat dan ajeg dibandingkan dengan dua daerah lainnya (Bandung dan Tasikmalaya). Kedua daerah di Priangan itu tidak 
memiliki sistem pemerintahan tradisional yang senantiasa melestarikan budaya leluhur seperti Kesultanan Cirebon. Seiring berjalannya waktu Kesultanan Cirebon terbagi menjadi tiga wilayah kekuasaan: Kasepuhan, Kanoman, dan Kacirebonan (Erwantoro, 2012: 179).

Pada perkembangannya urusan administratif pemerintahan dipegang oleh seorang Residen karena Cirebon merupakan sebuah ibu kota Keresidenan yang mencakup Indramayu, Cirebon, Majalengka, dan Kuningan (Verbeek, \& Fennema, 1896). Cirebon juga dikenal sebagai wilayah yang kosmoplitan karena terjadi akulturasi antara berbagai budaya asing (Arab, Cina, Eropa, India, dan Persia) dan pribumi.

Akulturasi berbagai budaya di atas tercermin dari beberapa motif batik khas Cirebon yakni Gajah Payung, Bouroq, dan Paksinagaliman (Atik, 2010: 15, 18, 3233). Secara historisitas menurut S. Ken Atik, Komarudin Kudiya, Herman Jusuf, Djalu Djatmiko, dan Zaini Rais (2010: 9) batik Cirebon terdiri dari beberapa versi, yaitu versi Keraton atau Klasik dan versi Kenduruan yang disebut batik Cina serta versi Trusmi yang diproduksi di sentra pembatikan Desa Trusmi dan sekitarnya. Batik versi Keratonan dimulai sejak 1430 $M$ oleh Pangeran Cakrabuana setelah beliau menunaikan ibadah haji. Pangeran Cakrabuana juga dikenal sebagai seniman. Perlambang pokok yang menjadi ciri motif keratonan adalah perlambang rohaniah dengan lambang-lambang Kangkungan, Manggisan, Wadasan, Pandanan dan sebagainya. Sedangkan kelompok kedua adalah perlambang yang bersifat jasmaniah atau kelompok fisik-material dengan lambang berupa Wuluhan, Mega Mendung, Kerisan, dan lain-lainnya.

Cirebon disebut kaya akan berbagai budaya disebabkan oleh sebagian besar kota-kota dagang terletak di tepi pantai. Contohnya Banten, adapula yang berkedudukan di muara sungai seperti Makassar (Leirissa, Ohorella, dan Tangkilisan, 2012: 27). Salah satu pusat perekonomian Cirebon selain sebagai kota perdagangan di Pesisir Utara Jawa Barat, Cirebon memiliki industri batik yang terkenal yakni Trusmi yang terletak di Kecamatan Plered, Kabupaten Cirebon. Berbicara mengenai Trusmi dalam dinamika kehidupan masyarakatnya, nyaris tidak ada yang berprofesi sebagai petani. Masyarakat lebih akrab pada tradisi membatik yang sudah berlangsung secara turun-temurun sejak abad ke-16 M, proses perkembangan Desa Trusmi yang kemudian dimekarkan menjadi Desa Trusmi Kulon dan Trusmi Wetan. Sejarahnya tidak terlepas dari peranan $\mathrm{Ki}$ Buyut Trusmi (pengikut setia) Sunan Gunung Jati yang memilih Trusmi sebagai daerah dalam menyebarkan Islam sekaligus melestarikan tradisi membatik di wilayah Kesultanan Cirebon (Kudiya, 2011: 15).

Bekerja sebagai perajin batik di Cirebon khususnya Trusmi adalah salah satu bentuk dari etnopreneurship yang sudah berlangsung secara turun-temurun. Salah satunya Batik Katura milik Katura, bila dirunut secara genealogis beliau adalah generasi ke delapan dari keluarganya yang berprofesi sebagai perajin sekaligus pengusaha batik (Septiani, wawancara, 13 Januari 2020).

Pengembangan industri batik di Desa Trusmi mengalami perkembangan yang signifikan pada tahun 1950-an, terutama setelah para pengusaha batik di sana memutuskan untuk mendirikan Koperasi Batik Budi Tresna (KBBT) pada 1955. Koperasi ini berada di bawah naungan (GKBI). KBBT memiliki tugas untuk melayani para anggota (pengusaha batik) yang ingin membeli alat-alat dan bahan membatik, serta menerima penjualan hasil karya industri batik di Desa Trusmi (Emalia, 2017: 223-224).

Batik Katura baru didirikan pada 1975, oleh pasangan suami-istri Katura dan Kuri'ah keduanya berasal dari keluarga perajin dan pengusaha batik di Cirebon. Katura dan Kuri'ah selain bertindak sebagai pemilik, juga bertindak sebagai 
perajin batik. Sebelum memiliki toko sendiri, proses penjualan produk Batik Katura dilakukan melalui paguyuban perajin batik keluarga yang bernama Batraman (Septiani, wawancara, 13 Januari 2020). Setelah memiliki toko tahun 1997 , proses penjualan dilakukan secara langsung kepada konsumen.

Batik Katura dikenal telah menjadi pusat pembelajaran membatik sejak 1980an, para pengunjung yang datang untuk belajar membatik di Batik Katura sangat beragam mulai dari wisatawan lokal hingga mancanegara (Asia dan Eropa) (Septiani, wawancara, 13 Januari 2020). Katura selalu dijadikan rujukan bagi siapapun yang ingin belajar membatik, karena beliau dikenal sebagai seorang seniman sekaligus pengusaha batik Trusmi, Cirebon.

Perkembangan industri batik di Trusmi tidak terlepas dari peranan para pengusaha batik yang merintis dan mengembangkan usaha disana, diantaranya H. Masina, H. Madmil dan H. Suhendro (Kudiya, 2011: 17). Setelah itu, baru berkembang lebih banyak lagi para pengusaha batik generasi selanjutnya. Salah satunya adalah Katura.

Tabel 2. Kondisi Pekerja Industri Batik Trusmi Tahun 1975-1998

\begin{tabular}{|c|c|c|c|}
\hline Tahun & $\begin{array}{l}\text { Jumlah } \\
\text { Pekerja }\end{array}$ & $\begin{array}{c}\text { Rata- } \\
\text { rata } \\
\text { Usia }\end{array}$ & $\begin{array}{l}\text { Rata-rata } \\
\text { Pendidikan }\end{array}$ \\
\hline 1975 & 1.280 & \multirow{11}{*}{$\begin{array}{l}12-55 \\
\text { Tahun }\end{array}$} & \multirow{11}{*}{$\begin{array}{c}\text { Tidak } \\
\text { Sekolah, } \\
\text { Putus } \\
\text { Sekolah, SD } \\
\text { dan SMP. }\end{array}$} \\
\hline 1982 & 1.260 & & \\
\hline 1983 & 1.190 & & \\
\hline 1985 & 1.125 & & \\
\hline 1986 & 1.107 & & \\
\hline 1987 & 1.107 & & \\
\hline 1992 & 410 & & \\
\hline 1993 & 405 & & \\
\hline 1994 & 405 & & \\
\hline 1995 & 400 & & \\
\hline 1998 & 200 & & \\
\hline
\end{tabular}

Sumber: Feriadi, 2011.

Jumlah perajin batik dari 1955 sejak berdirinya KBBT cenderung menurun. Hal itu disebabkan banyaknya produk-produk tekstil bermotif batik yang membanjiri daerah-daerah yang sebelumnya didominasi oleh produk-produk batik asal Trusmi seperti Majalengka dan Kuningan. Produk tekstil bermotif batik itu, sebagian besar berasal dari Jawa Tengah.

Keadaan semakin diperparah dengan semakin banyaknya penyelundupan yang kabarnya sebagian besar berupa tekstil. Penyelundupan merupakan salah satu faktor utama yang memukul industri tekstil dalam negeri seperti batik (Tempo, 1971). Tidak heran jika jumlah perajin batik Trusmi dari masa keemasannya 1955 sampai 1998 terus menurun, selain kalah bersaing dalam hal efisiensi dan modal produksi. KBBT pun semakin melemah dengan banyaknya pengusaha yang bangkrut dan perajin batik yang beralih profesi ke pekerjaan yang lebih stabil pemasukannya dan dapat menjamin kesejahteraan di hari tua.

\section{Industri Batik di Tasikmalaya}

Tasikmalaya adalah daerah yang tumbuh secara berkelanjutan dari sektor usaha rumah tangga, kecil, dan menengah. Salah satu yang cukup dominan ialah industri batik yang pada awal kemerdekaan merupakan usaha yang bersifat swadaya. Tasikmalaya memiliki beberapa wilayah yang fokus memproduksi batik di antaranya di Desa Sukapura (Kecamatan Sukaraja), Desa Parakannyasag (Kecamatan Indihiang), dan Desa Nagarasari (Kecamatan Cipedes). Selain itu, batik Tasikmalaya banyak dipengaruhi oleh batik asal Jawa Tengah hal ini didasarkan pada alasan kedekatan geografis dengan Purwokerto dan Banyumas sebagai tempat produksi batik Keraton (Pradito, 2010: 42).

Saat jaman kolonial Belanda sektor perdagangan dan ekonomi kerakyatan didominasi serta cenderung dimonopoli oleh warga negara kelas dua yakni etnis Timur Asing (Cina, Arab, Jepang, India dan lain-lain) khususnya etnis Cina. Akibat monopoli yang dilakukan etnis Cina 
membuat para pengusaha pribumi mengalami kesulitan dalam mendapatkan bahan-bahan baku untuk membatik dengan harga terjangkau, tidak lama kemudian sebagai bentuk perlawanan pengusaha batik pribumi di Tasikmalaya terhadap pedagang Cina. Mereka memutuskan untuk mendirikan Koperasi Mitra Batik sebagai jalan alternatif untuk mencari pendanaan dan bahan-bahan baku membatik secara terjangkau.

Lahirnya Koperasi Mitra Batik didasarkan pada sebuah kegelisahan bersama pengusaha pribumi. Menurut (Prananta, 2019: 12) gerakan seperti ini biasanya muncul akibat masalah dominasi kekuasaan politik penguasa, opresi, kesenjangan masyarakat negara yang dibagi sesuai ras, dan berujung pada upaya 'mengakhiri' kondisi tersebut. Kondisi ekonomi-sosial Tasikmalaya sudah terkenal dengan perkumpulan pengusaha batik yang memiliki inisiatif dan jiwa wirausaha yang tinggi. Hal ini turut mendorong lahirnya Koperasi Mitra Batik yang diinisiasi oleh Naseh, Enie, dan Dion. Industri batik Tasikmalaya kemudian berkembang pesat seiring dengan semakin luasnya pangsa pasar di Priangan.

Saat pertama kali

Asep mengembangkan usaha batik keluarga pada 1945, Asep termasuk generasi pertama pengusaha batik Tasikmalaya pasca kemerdekaan Indonesia dan generasi kedua dari keluarganya. Saat itu, kondisi perekonomian Indonesia sedang mengalami masa-masa tersulit setelah lepas dari cengkraman para penjajah. Keadaan berangsur-angsur membaik setelah memasuki era Orde Baru 1967.

... lembaga baru, seperti koperasi desa, akan mempunyai peranan integratif yang lebih besar kalau ia tidak justru membagi-bagi masyarakat desa ke dalam kelompok-kelompok ekonomi (Kuntowijoyo, 2018: 92-93).

Asep melanjutkan usaha milik keluarga yang telah diwariskan secara turun-temurun. Asep mengembangkan usaha keluarga yang terletak di Desa Parakannyasag, Kecamatan Indihiang, Kabupaten Tasikmalaya dengan memperkerjakan beberapa perajin batik tulis (pangeuyeuk tulis) di daerah sekitar tempat industri batiknya didirikan. Umumnya selain mempekerjakan para pangeuyeuk tulis yang sudah mahir, Asep juga membuka kesempatan bagi generasi yang lebih muda untuk bisa belajar membatik tulis kepada para pangeuyeuk tulis yang lebih berpengalaman sambil magang (Supriyadi, wawancara, 17 November 2018).

Asep adalah salah satu di antara sekain banyak pengusaha batik di Tasikmalaya yang turut bergairah dengan seiring membaiknya perekonomian masyarakat Indonesia. Hal ini berimplikasi terhadap daya beli masyarakat yang lebih baik dan permintaan dari pasar domestik senantiasa meningkat meskipun cenderung fluktuatif dan relatif kurang stabil karena adanya produk tekstil yang lebih murah. Pada 1970-an adalah awal-mula kehancuran industri batik di Tasikmalaya, karena adanya mesin cetak kain tekstil bermotif batik (printing), mesin printing itu awalnya berkembang dari Jawa Tengah (Supriyadi, wawancara, 18 Januari 2020).

Dalam proses membuat desain batik, Asep memperkerjakan beberapa desainer batik yang berasal dari daerah Pekalongan. Mereka banyak yang bekerja ke Tasikmalaya setelah lesu dan hancurnya industri batik di Pekalongan, akibat invasi kain tekstil bermotif batik dari Jawa Tengah (Supriyadi, wawancara, 18 Januari 2020). Tidak heran, jika berbagai motif batik Tasikmalaya cenderung banyak yang menggunakan warna cerah khas batik pesisiran akibat pengaruh para perajin batik Pekalongan yang bermigrasi ke Tasikmalaya.

Industri Batik milik Asep di Desa Parakannyasag, Kecamatan Indihiang menjadi sumber mata pencaharian masyarakat sekitar yang memiliki keterampilan dalam membatik. Umumnya tahun 1965-1980-an akhir mereka yang 
bekerja di industri ini adalah masyarakat berusia 50 tahun ke atas. Hal ini dipengaruhi oleh derasnya arus urbanisasi ke kota-kota besar di Jawa Barat (Bandung, Karawang, Bekasi, Bogor, dan Depok). Memasuki tahun 1990-an mulai banyak masyarakat yang bekerja di tempat kelahirannya dengan rata-rata usia > 30 tahun.

Tabel 3: Kondisi Pekerja Asep Batik 1967-

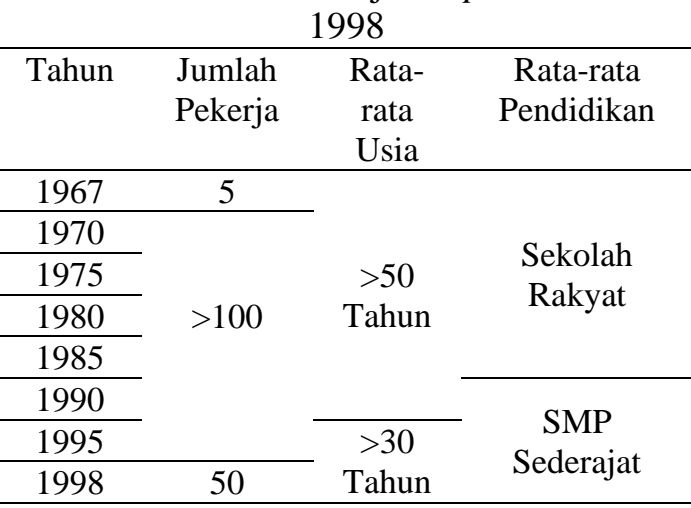

Sumber: Wawancara dengan Deden Supriyadi.

53 Tahun. Pemilik Deden Batik. 18 Januari 2020 di Bengkel Deden Batik, Kota Tasikmalaya.

Akhir 1990-an produksi di daerah kampung batik Desa Parakannyasag, Kecamatan Indihiang pun terdampak krisis moneter yang berimbas menurunnya tingkat produksi. Banyak perajin yang "dirumahkan" untuk sementara waktu sampai keadaan perekonomian negara membaik.

Kerugian akibat pesanan yang masih dikerjakan lumayan banyak, sehingga beban kerja sebagian perajin batik yang masih bekerja cukup berat karena harus menyelesaikan pekerjaan dua hingga tiga kali lipat dari beban kerja semula. Demi mencapai target produksi yang telah disetujui sebelumnya, meskipun merugi Asep Batik tidak gulung tikar. Jumlah anggota Koperasi Mitra Batik yang semula memiliki anggota berkisar 700-an, menurun drastis menyisakan 400 anggota aktif pada 1998 akibat krisis moneter (Supriyadi, wawancara, 18 Januari 2020).
Hal serupa disampaikan oleh Amin Mudzakkir (2005) dalam skripsinya yang berjudul Kaum Santri Kota: Pengusaha, Perubahan Ekonomi, dan Islam di Kota Tasikmalaya, 1930-1980-an. Koperasi Mitra Batik berkembang pesat pada 1950an, ditandai dengan didirikannya pabrik kain mori, kemudian merosot di era Orde Baru dan akhirnya kolaps menjelang krisis moneter 1998 (Mudzakkir, 2017: 59).

\section{PENUTUP}

Persebaran industri batik di Bandung, Cirebon, dan Tasikmalaya 1967-1998 dilatarbelakangi oleh peristiwa sejarah dan diaspora masyarakat dari abad ke-17 hingga abad ke-20 di Pulau Jawa. Persinggungan antara dua budaya yang berbeda (Sunda dan Jawa) saling memengaruhi satu sama lain yang tergambarkan dengan adanya budaya membatik di beberapa daerah dan perbedaan dalam tradisinya di Jawa Barat.

Apabila di masyarakat Jawa motif batik menandakan stratifikasi sosial sedangkan, di masyarakat Sunda tidak demikian keadaannya. Industri batik di Bandung dan Tasikmalaya karena tidak dibesarkan oleh lingkungan pemerintahan tradisional (kesultanan) seperti di Cirebon, pemakaian batik di kalangan masyarakat lebih egaliter. Berbeda dengan Cirebon yang terpengaruh oleh kultur hierarkis Jawa yang memisahkan motif pakaian Raja, Priyayi, dan Kawula seperti di Surakarta dan Yogyakarta.

Tingkat kesejahteraan masyarakat akibat adanya industri batik bisa terbilang tidak terlalu signifikan, karena bekerja sebagai perajin batik terkategorisasi sebagai pekerja informal yang bersifat kontraktual. Hal ini juga didorong oleh kurangnya kesempatan untuk memperluas pasar hingga ke luar negeri, akibat keterbatasan modal, manajemen yang dijalankan secara tradisional, dan efisiensi dalam produksi yang serba terbatas karena kemampuan produksi yang berbanding lurus dengan jumlah pekerja yang tersedia dan terampil. Jauh akan lebih baik jika 
pemerintah berinisiatif untuk melakukan pembinaan usaha dan membantu regenerasi perajin batik yang sampai saat ini jumlahnya sangat terbatas dan langka.

\section{DAFTAR SUMBER}

Achmad, S. W. (2016). Sejarah KerajaanKerajaan Besar di Nusantara.Yogyakarta: Araska.

Atik, S. K., Kudiya, K., Jusuf, H., Djatmiko, D., dan Rais, Z. (2010). Buku Saku Batik Jawa Barat Jilid II. Bandung: Yayasan Batik Jawa Barat (YBJB).

Basundoro, P. (2016). Pengantar Sejarah Kota.Yogyakarta: Ombak.

Boow, J. (1988). Symbol and Status in Javanese Batik. Monograf Series No. 7. Asian Studies Centre: University of Western Australia.

Djajusman, D. S. (1993). Di Seberang Gerbang Pabrik: Asrama Buruh Perempuan. Prisma 21, 51-58.

Emalia, I. (2017). Geliat Ekonomi Kelas Menengah Muslim di Cirebon: Dinamika Industri Batik Trusmi 1900-1980. AlTuras, 23 (2), 211-230.

Erwantoro, H. (2012). Sejarah Singkat Kerajaan Cirebon. Jurnal Patanjala, 4 (1), 170-183.

Feriadi. (2011). Perkembangan Industri Batik Trusmi 1955-2005. Skripsi Fakultas Sastra Universitas Padjadjaran.

Katam, S. (2014). Gemeente Huis. Bandung: Kiblat Buku Pustaka.

Kudiya, K. (2011). Batik Eksistensi untuk Tradisi. Jakarta: Dian Rakyat.

Kuntowijoyo. (2018). Demokrasi \& Budaya Birokrasi. Yogyakarta: IRCiSoD.

Lee, E. S. (1976). Laporan penelitian: Suatu Teori Migrasi. Yogyakarta: Lembaga Kependudukan Universitas Gadjah Mada.

Leirissa, R. Z., Ohorella, G. A., dan Tangkilisan, Y. B. (2012). Sejarah Perekonomian Indonesia. Yogyakarta: Ombak.

Mudzakkir, A. (2017). Konservatisme Islam dan Intoleransi Keagamaan di
Tasikmalaya. Multikultural \& Multireligius, 16 (1), 57-74.

Mulyana, A. (2018). Negara Pasundan 19471950. Yogyakarta: Ombak.

Noer, D. (2015). Mohammad Hatta. Jakarta: Buku Kompas.

Nurainun, Heriyana dan Rasyimah. (2008). Analisis Industri Batik di Indonesia. Fokus Ekonomi, 7 (3), 124-135.

Permanasari, I. \& Cahanar, P (Ed). (2019). Kisah Goresan Malam. Jakarta: Kompas.

Pradito, D., Jusuf, H., dan Atik, S. K. (2010). The Dancing Peacock Colours and Motifs of Priangan Batik. Jakarta: Gramedia Pustaka Utama.

Prananta, A. W. (2019). Sejarah Kelas Menengah (Dari Zaman Kerajaan hingga Indonesia Modern). Malang: Intrans Publishing.

Salam, M. (2017). Sanghyang Siksa Kandang Karesian, diakses 24 Februari 2020, dari http://soekapoera.or.id/2017/04/02/sangh yang-siksa-kandang-karesian/

Sari, S. (9 September 2019). Wawancara.

Septiani, M. (13 Januari 2020). Wawancara.

Sunarya, Y. Y. (2010) Batik Priangan Modern dalam Konstelasi Estetik dan Identitas. Pendidikan Seni KAGUNAN, 4 (2), 1-11.

Supriyadi, D. (17 November 2018). Wawancara.

Supriyadi, D. (18 Januari 2020). Wawancara.

Sutopo, I. (2011) Produktivitas dan Ketahanan Bisnis Industri Kecil (Studi Empiris Industri Batik Tulis Trusmi Kecamatan Plered Kabupaten Cirebon). Dinamika Keuangan dan Perbankan, 3 (1), 102-112.

Tempo. (1993, Mei, 15). Kemiskinan dan Kesenjangan. Tempo, 12.

Tempo. (1971, Agustus, 14). Kota Tanpa Batik. Tempo, 19-20.

Tempo. (1971, Juli, 3) Tentang Buruh Murah Indonesia. Tempo, 46.

Tempo. (1971, Juni, 19). Jang Terlindung dan Terpukul. Tempo, 43.

Trade Research \& Development Agency. (2008). Indonesian Batik A Cultural 
Beauty. Jakarta: Departemen Perdagangan Republik Indonesia.

Verbeek, R. D. M \& Fennema, R. (1896).

"Geologische Beschrijving van Java en Madoera" dalam Uitgegeven Op Last Van

Zijne Excellentie Den Gouverneur-

Generaal Van Nederlandsch-Indie.

ATLAS. Amsterdam: Joh. G. Stemler Cz.

Warsito, R. (2017). Antropologi Budaya.

Yogyakarta: Ombak. 